The Israeli Journal of Aquaculture - Bamidgeh, IJA_69.2017.1399, 8 pages

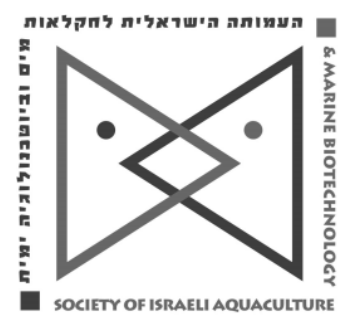

The IJA appears exclusively as a peer-reviewed on-line open-access journal at http://www.siamb.org.il. To read papers free of charge, please register online at registration form.

Sale of IJA papers is strictly forbidden.

\title{
Pinus tabulaeformis Pollen as Replacement for 17-alpha- methyltestosterone in the Diet of Oreochromis niloticus Larvae for Sex Reversal and Growth
}

\author{
Cherry T. Nian1,3, Barry Leonard M. Tumbokon 2, Augusto E. \\ Serrano, Jr.1,2*
}

\begin{abstract}
${ }^{1}$ Institute of Aquaculture, College of Fisheries and Ocean Sciences, University of the Philippines Visayas, Miagao, Iloilo, Philippines

${ }^{2}$ National Molecular Biology and Biotechnology, University of the Philippines Visayas, Miagao, Iloilo, Philippines

${ }^{3}$ Mindanao State University, Tawi-Tawi College of Technology and Oceanography, Bongao, Tawi-Tawi, Phillippines
\end{abstract}

Keywords: hormonal induction; pine pollen; attractability; digestive enzymes; Nile tilapia

\begin{abstract}
Three experiments were conducted to investigate the use of pollen from Pinus tabulaeformis (PP), as a possible replacement for synthetic 17-alphamethyltestosterone (MT) in Nile tilapia, Oreochromis niloticus larvae diets. In experiment 1 , the attractability of a diet containing PP $(640 \mathrm{mg} / \mathrm{kg})$ compared to a control diet containing no PP was assessed. Experiment 2, lasting 8 weeks, evaluated the effects of PP on growth, food conversion efficiency, survival, and sex inversion compared with that of $17 \mathrm{a}$-methyltestosterone (MT). Results showed that after 60 days of feeding, $100 \%$ of Nile tilapia fed the MT diet converted to male; this was statistically similar to the percentage of fish fed the PP diets ( $81.0 \%$ to $89.1 \%$ male, $p<0.05)$. Results of the growth trial showed that final weight (FW) and weight gain (WG) of fish fed diets containing $0.08 \mathrm{~g} / \mathrm{kg} \mathrm{PP}$ and $0.64 \mathrm{~g} \mathrm{PP} / \mathrm{kg}$ were significantly higher than those fed the MT diet $(p<0.05)$. Feed intake $(\mathrm{FI})$ of all experimental fish were statistically similar $(p>0.05)$. The group fed $0.08 \mathrm{~g} \mathrm{PP} / \mathrm{kg}$ diet exhibited significantly higher SGR than the MT group. The MT group exhibited lower food conversion efficiency (i.e. higher FCR) than the control group. Fish fed diets containing 0.08 and $0.64 \mathrm{~g} \mathrm{PP} / \mathrm{kg}$ exhibited better FCR than those fed the MT diet. Survival was statistically similar for all dietary treatments $(p>0.05)$. In experiment 3, fish larvae were fed: no PP (control diet), a medium dose $(0.32 \mathrm{~g} / \mathrm{kg})$, and a high dose $(0.64 \mathrm{~g} / \mathrm{kg})$ of PP for 14 days and assayed for alpha amylase and trypsin activities. Results showed that diets containing PP were significantly more attractive to the fish than the control diet $(p<0.05)$ for the first $5 \mathrm{~min}$. At the $6^{\text {th }} \mathrm{min}$, results were statistically similar for both PP diets. In conclusion, PP could replace MT in effecting sex reversal from female to male with statistically similar results; it could also promote better growth and food conversion efficiency at the minimum dietary level of $0.08 \mathrm{mg} \mathrm{PP} / \mathrm{kg}$.
\end{abstract}

* Augusto E. Serrano, Jr., Corresponding author: E-mail: aeserrano@up.edu.ph 


\section{Introduction}

Tilapia aquaculture in the Philippines faces numerous challenges including degradation of quality fingerlings due to inbreeding, insufficient supply of quality fry, high cost of farm inputs, and poor-quality feeds, among other problems. The use of mix-sex tilapia for culture results in early sexual maturation and breeding which results in stunted growth due to overpopulation. Monosex culture is the best solution to this problem. Of the various methods of producing single sex populations of tilapia, artificial sex reversal is the most effective, efficient, and cost-effective. It may increase the yield of large-sized tilapia by 30-50 percent because of the faster growing males compared to females, and controlling reproduction. In the Philippines, up to $90 \%$ of the tilapia cultured is sexreversed and in other countries such as the United States, Canada, Israel, and the Caribbean, at least 50\% (Tacio, 2014).

Among effective androgens for hormonal induction of sex reversal in fish, 17amethyltestosterone (MT) is the most widely used and has been tested in more than 25 species of fish (Pandian and Sheela 1995). It has become the standard agent to produce all-male tilapias. MT is a synthetic male hormone which mimics the naturally-produced hormone testosterone and consequently is used in hormone replacement therapy in humans (Bhasin et al, 1998). It is also used in the promotion of weight gain in livestock (Velle, 1982). There are concerns with the health risks of MT to consumers and this concern may be well founded if administered during late stage of development, and in higher than the recommended dosages. There are also concerns regarding MT residues remaining in the water system for a long period of time following release of waste water from hatcheries.

Little research has been conducted into pine pollen which is a Chinese traditional medicine and has received little attention as an androgenic and anabolic agent in aquaculture despite being advertised as a feed additive for all animals world-wide. We have tested it on African catfish Clarias gariepinus and found it to be an effective androgenic and anabolic agent (Adenigba et al, in press). Pollen of Pinus spp. contains testosterone (Šaden-Krehula et al,1971; Zhong-han et al, 1994), epitestosterone, androstenedione, and other derivatives of testosterone (Šaden-Krehula et al, 1971; Jones \& Roddick, 1988). Although some information is available in popular media on the possible utilization of PP for the induction of sex reversal in fish, no reports involving serious experimental trials have been available to date. Thus, exploratory research to investigate its androgenic and anabolic effects on the Nile tilapia is in order.

\section{Materials and Methods}

The experiments were conducted at the National Institute of Molecular Biology and Biotechnology (NIMBB) Laboratory at the University of the Philippines Visayas, Miagao, Iloilo, Philippines.

Preparation of experimental feeds. Pine pollen (PP) powder and 17- $\alpha$-methyl testosterone (MT) (Zhongshan Yuanhang Co., Zhejiang, China) were each dissolved in 95\% ethanol and added to the basal diet (a commercial feed; Santeh Feeds Corp. Quezon City, Philippines). Proximate composition of the basal diet as indicated on the product label is shown in Table 1 . Hormone preparations were added to the feed and thoroughly mixed to produce the desired levels in each treatment. The mixtures were air dried at room temperature to evaporate ethanol, oven dried at $60^{\circ} \mathrm{C}$ for $12 \mathrm{~h}$, crumbled, sieved to appropriate sizes and stored at $4^{\circ} \mathrm{C}$ until use.

Table 1. Proximate composition of the commercial tilapia fry booster on a dry weight basis (\%).

\begin{tabular}{lc}
\hline & $\%$ \\
\hline Crude protein & 45.0 \\
Crude fat & 8.0 \\
Crude fiber & 5.0 \\
Ash & 16.0 \\
Moisture & 12.0 \\
Nitrogen-free extract (NFE) & 14.0 \\
\hline
\end{tabular}


Pine Pollen Attractability. Three tailor-made glass tanks (Suresh et al, 2011) were utilized for the assessment of attractability of pine pollen to Nile tilapia. Each tank measuring $90 \times 30 \times 30 \mathrm{~cm}$ in length, width, and height respectively, was constructed of clear glass with an acclimatization chamber at one end and three feeding chambers at the other end. A movable glass shutter separated the acclimatization and feeding chambers. Each feeding chamber had an opening to allow free access of tilapia to the basal and test diets. The tanks were set up in a room that received light from fluorescent tubes placed approximately 5 meters high on the ceiling.

Attractability of feed was tested simultaneously: the control and the PP diet were placed in two compartments of the attractability tank while the remaining compartment was left empty. Measurements were repeated for a total of 6 times in two days beginning at 900 o'clock; the positions in which experimental diets were placed were changed randomly. For each measurement, ten tilapia fingerlings (weighing about $3.2 \mathrm{~g}$ ) were randomly placed into the acclimatization chamber, and allowed to acclimatize for $1 \mathrm{~h}$. Then $1 \mathrm{~g}$ each of the control and test feeds were placed simultaneously, but separately, in two random chambers, and the third chamber remained empty. One minute after the placement of the feeds, the moveable glass shutter was raised to allow access to the feeds. Every minute up to 6 minutes (at 1,2,3,4,5, and 6 minutes) following the raising of the shutter, the number of fish in the feeding chamber was counted and recorded.

Sex reversal and growth experiment. Six experimental diets containing graded levels of PP, namely, 0 (negative control), $0.08,0.16,0.32$, and $0.64 \mathrm{~g} \mathrm{PP} / \mathrm{kg}$ of feed, were used to evaluate the effects of dosage on sex reversal, growth performance, and food conversion efficiency of the Nile tilapia. A positive control diet contained MT at $0.6 \mathrm{~g} / \mathrm{kg}$. Each diet was fed to three replicate tanks of the larvae.

The experiment was conducted in a closed recirculating water system composed of 18 tanks ( 50 L capacity) for 8 weeks. Five hundred forty larvae were randomly distributed into 18 tanks at a density of 30 larvae/tank. A separate group of larvae were bulk weighed to determine initial body weight, and were then discarded. Larvae in the experimental tanks were all fed the negative control diet (no PP, no MT) for 3 days after which, they were fed the corresponding test diets at an estimated rate regarded as ad libitum. The ad libitum rate was estimated at the start, and every 7 days, and was used as the basis of feeding for the next 6 days. At the termination of the experiment, the larvae were again bulk weighed and sex determined by ocular inspection. Fry was regarded as male when it exhibited elongated and pointed genital papilla, and regarded as female when short and rounded.

Uneaten feed and feces were siphoned off daily and the water replenished immediately thereafter. The tanks were continuously aerated in a closed recirculating system. The system consisted of a physical filter tank (containing gravel and sand), a biological filter (containing previously disinfected oyster shells) and a sedimentation tank with fiber pad filter in a total volume of $1,400 \mathrm{~L}$ of water flowing at $30 \mathrm{~L} / \mathrm{h}$. Water temperature and $\mathrm{pH}$ were measured twice daily, dissolved oxygen (DO) twice weekly, and nitrite and total ammonia (using commercially available kits) once weekly.

Enzyme assay. To determine the effects of the diet containing either PP or MT on the digestive enzymes alpha amylase and trypsin, a separate experiment was done in which Nile tilapia larvae were fed either the basal diet only, a medium dosage $(0.32 \mathrm{~g} / \mathrm{kg})$ or a high dosage of PP $(0.64 \mathrm{~g} / \mathrm{kg})$ for 14 days. At the termination of the experiment, the fry were sacrificed, and the whole body activity of the two enzymes were assayed.

Whole body of larvae were homogenized in 20 vol. of cold $50 \mathrm{mM}$ citrate phosphate buffer, $\left(\mathrm{pH} \mathrm{7.0)}\right.$ ), and centrifuged at $4000 \mathrm{rpm}$ for $15 \mathrm{~min}$ at $4^{\circ} \mathrm{C}$ (Serrano \& Traifalgar, 2012). The supernatant was used as the crude enzyme for the assays.

Optimization of assay conditions were conducted to calibrate the enzyme activity to be used for the routine assay. Enzyme activities of alpha amylase and trypsin increased linearly with time up to $10 \mathrm{~min}$, beyond which they decreased. The two enzymes exhibited linear activity with the volume of enzyme preparation up to $0.6 \mathrm{ml}$. Thus, in the routine assay, the reaction time used was $10 \mathrm{~min}$ and the volume of crude extract was $0.6 \mathrm{ml}$. Under these conditions, the activity of both alpha amylase and trypsin were considered to be initial velocities. 
Alpha amylase was assayed (Bernfeld, 1955) and the increase in reducing power of a buffered starch solution was measured with 3,5-dinitrosalicylic acid (DNS) at $540 \mathrm{~nm}$. The assay mixture consisted of $1.0 \mathrm{~mL}$ soluble starch $(10 \mathrm{mg} / \mathrm{ml}), 0.6 \mathrm{~mL}$ enzyme preparation and $0.4 \mathrm{~mL}$ of $50 \mathrm{mM}$ citrate phosphate buffer $(\mathrm{pH} \mathrm{7.0)}$ in a final volume of $2.0 \mathrm{ml}$. The reaction was carried out at $25^{\circ} \mathrm{C}$ for $10 \mathrm{~min}$ and was terminated by adding $44.0 \mathrm{mM}$ DNS solution. The mixture was then heated for $5 \mathrm{~min}$ in boiling water, cooled in running tap water, and absorbance read at $546 \mathrm{~nm}$. Optical density was calculated by subtracting the absorbance of the zero time from those of the reaction samples. Specific amylase activity was expressed as $\mathrm{mg}$ maltose liberated from starch/h/mg protein. The concentration of maltose as a product of the reaction was estimated using a calibration curve with maltose as standard.

Trypsin activity was measured (Geiger \& Fritz, 1988) using a synthetic substrate, $N$ $a$-benzoyl-L-arginine $p$-nitroaniline hydrochloride (BAPNA) specific only to trypsin and not to any other serine protease. The reaction mixture consisted of $1.25 \mathrm{~mL}$ substrate solution $(1.0 \mathrm{mM}), 0.6 \mathrm{ml}$ crude enzyme extract, and $0.15 \mathrm{ml}$ of $50 \mathrm{mM}$ citrate phosphate buffer in a final volume of $2.0 \mathrm{ml}$. The reaction was stopped after 10 min by adding $0.25 \mathrm{ml}$ of $30 \%$ acetic acid and the optical density read at $405 \mathrm{~nm}$. The amount of $p$ nitroaniline released $/ \mathrm{h} / \mathrm{ml}$ enzyme was determined using the extinction coefficient 9, 960 $\mathrm{cm} / \mathrm{M}$ (Kassell 1970). Trypsin activity was expressed as umoles of $p$-nitroaniline produced/h/mg protein.

Total protein was measured (Bradford, 1976) using blue dye (Coomassie Brilliant Blue G-250) that binds with proteins. The assay is based on the observation that the absorbance maximum for an acidic solution of Coomassie Brilliant Blue G-250 shifts from $465 \mathrm{~nm}$ to $595 \mathrm{~nm}$ when binding to protein occurs. Both hydrophobic and ionic interactions stabilize the anionic form of the dye, causing a visible color change. Bovine Serum Albumin (BSA) was used as standard. Five $\mathrm{mL}$ of the dye reagent was added to $100 \mu \mathrm{l}$ of test sample, incubated for at least $5 \mathrm{~min}$, and the absorbance read at $595 \mathrm{~nm}$.

Estimation of response parameters. The following formulae were used to estimate the various parameters in the feeding trials:

$$
\begin{gathered}
\text { Sex reversal efficiency }=(\text { No. of male fry/No. of fry }) \times 100 \\
\text { Survival rate }(\%)=100 *(\text { final count/initial count }) \\
\text { Weight gain, WG }(\mathrm{g})=\text { FABW-IABW }
\end{gathered}
$$

Where: FABW = Final average body weight $(\mathrm{g})$ and

IABW $=$ Initial average body weight $(\mathrm{g})$

$$
\begin{gathered}
\text { Specific Growth Rate }\left(\text { SGR, \% day }{ }^{-1}\right)=100 *(\text { In FABW-In IABW }) / \text { days } \\
\text { Protein efficiency ratio }(\text { PER })=\text { WG } / F^{*} \text { Diet CP (in decimal) } \\
\text { FCR }=\text { FI }(\mathrm{g}) / W G(g)
\end{gathered}
$$

Where $\mathrm{FI}=$ total individual feed intake $(\mathrm{g})$

Statistical Analysis. Statistical Package for Social Sciences (SPSS) version 20 software was used to perform statistical analysis. Data from the study were presented as mean \pm standard error of the mean (SEM) and were tested for normality and variance homogeneity. The one-way analysis of variance (ANOVA) was used on data on the final percentage of male, growth, food conversion efficiency, enzyme specific activities, and survival at alpha $=0.05$. Data on PP attractability were analyzed using Student t-test. Post hoc analyses were done where appropriate using Duncan's Multiple Range Test (DMRT) to rank the means. 


\section{Results}

Results of the attractability tests are presented in Table 2. The data showed that for the first 5 min, the diet containing PP significantly was more attractive to the Nile tilapia than the control diet $(p<0.05)$ for the first $5 \mathrm{~min}$. Visible behavioral differences in the fish being offered the two diets in separate feeding chambers were apparent immediately after allowing access to the feed. The percentage of fish entering the chambers of the control and test diets after 6 min became statistically similar.

Table 2. Attractability of the basal diet only and of the test diet containing $0.64 \mathrm{~g} / \mathrm{k}$ pine pollen. Data expressed as the number of fish which entered the feeding chamber divided by the total number of fish (Mean \pm SEM).

\begin{tabular}{|c|c|c|c|c|c|c|}
\hline & \multicolumn{6}{|c|}{$\%$ fish in the chamber } \\
\hline & $1 \mathrm{~min}$ & $2 \min$ & $3 \min$ & $4 \min$ & 5 min & $6 \mathrm{~min}$ \\
\hline Control Diet* & $15.0 \pm 5.0^{a}$ & $15.0 \pm 5.0^{a}$ & $15.0 \pm 4.3^{a}$ & $20.0 \pm 3.7^{a}$ & $23.3 \pm 3.3^{a}$ & $21.7 \pm 4.8^{a}$ \\
\hline Test Diet** & $43.3 \pm 9.2^{b}$ & $43.3 \pm 9.2^{b}$ & $45.0 \pm 5.0^{b}$ & $43.3 \pm 4.2^{b}$ & $35.0 \pm 5.0^{b}$ & $26.7 \pm 4.2^{a}$ \\
\hline
\end{tabular}

Means in the same column sharing the different superscript letters are significantly different when Student t-test was conducted $(p<0.05)$

*basal diet containing no pine pollen

**basal diet containing $640 \mathrm{mg}$ pine pollen/kg diet

For the sex reversal, the genital papillae of the fry for sex determination were very distinguishable at the termination of the growth trial. The MT diet resulted in $100 \%$ inversion to male after 8 weeks of feeding but was statistically similar with those of the PP groups (Table 3 ). Fish fed the PP diets exhibited very high percent sex conversion of $81.0 \%$ to $89.1 \%$. Almost half of the fish fed the control diet were male $(50.5 \%)$ and almost half female (49.5\%).

Table 3. Growth performance, feed efficiency, survival and sex reversal efficiency of the Nile tilapia Oreochromis niloticus fed diets containing various dosage of pine pollen (PP) with a negative control (containing no PP) and positive control (methyltestosterone, MT) diets. Values given are Mean $\pm \mathrm{SEM} ; \mathrm{n}=3$.

\begin{tabular}{lllllllll}
\hline$(g / k g$ & $I W$ & $F W(g)$ & $W G(g)$ & $F I(g)$ & $\begin{array}{l}S G R \\
(\% / d a y)\end{array}$ & $F C R$ & SURV & Final \% male \\
$P P)$ & $(g)$ & & & & \\
0.00 & 0.01 & $4.0 \pm 0.2^{\mathrm{b}}$ & $3.9 \pm 0.2^{\mathrm{b}}$ & $4.1 \pm 0.1^{\mathrm{b}}$ & $4.3 \pm 0.1^{\mathrm{ab}}$ & $1.0 \pm 0.0^{\mathrm{b}}$ & $76.0 \pm 4.0^{\mathrm{a}}$ & $50.5 \pm 11.7^{\mathrm{b}}$ \\
0.08 & 0.01 & $5.9 \pm 1.0^{\mathrm{a}}$ & $5.8 \pm 1.0^{\mathrm{a}}$ & $6.0 \pm 1.1^{\mathrm{ab}}$ & $4.6 \pm 0.1^{\mathrm{a}}$ & $1.0 \pm 0.0^{\mathrm{b}}$ & $77.3 \pm 11.7^{\mathrm{a}}$ & $81.0 \pm 7.1^{\mathrm{ab}}$ \\
0.16 & 0.01 & $4.7 \pm 0.5^{\mathrm{ab}}$ & $4.7 \pm 0.5^{\mathrm{ab}}$ & $5.1 \pm 0.5^{\mathrm{ab}}$ & $4.4 \pm 0.1^{\mathrm{ab}}$ & $1.1 \pm 0.0^{\mathrm{ab}}$ & $76.0 \pm 2.30^{\mathrm{a}}$ & $87.7 \pm 7.0^{\mathrm{a}}$ \\
0.32 & 0.01 & $4.8 \pm 0.2^{\mathrm{ab}}$ & $4.7 \pm 0.2^{\mathrm{ab}}$ & $4.6 \pm 0.2^{\mathrm{b}}$ & $4.5 \pm 0.1^{\mathrm{ab}}$ & $1.0 \pm 0.0^{\mathrm{b}}$ & $78.7 \pm 8.74^{\mathrm{a}}$ & $89.1 \pm 3.6^{\mathrm{a}}$ \\
0.64 & 0.01 & $5.9 \pm 0.4^{\mathrm{a}}$ & $5.8 \pm 0.4^{\mathrm{a}}$ & $6.9 \pm 1.0^{\mathrm{a}}$ & $4.5 \pm 0.1^{\mathrm{ab}}$ & $1.2 \pm 0.1^{\mathrm{ab}}$ & $69.3 \pm 10.4^{\mathrm{a}}$ & $85.2 \pm 10.6^{\mathrm{ab}}$ \\
$M T^{*}$ & 0.01 & $4.0 \pm 0.2^{\mathrm{b}}$ & $4.0 \pm 0.3^{\mathrm{b}}$ & $5.0 \pm 0.2^{\mathrm{ab}}$ & $4.2 \pm 0.1^{\mathrm{b}}$ & $1.3 \pm 0.0^{\mathrm{a}}$ & $68.0 \pm 2.3^{\mathrm{a}}$ & $100.0 \pm 0.0^{\mathrm{a}}$
\end{tabular}

Means in the same column sharing the different superscript letters are significantly different $(P<0.05)$

$\mathrm{SEM}=$ standard error of the mean; IW=initial weight; $\mathrm{FW}=$ final weight; $W G=$ weight gain; FI = feed intake; $S G R=$ specific growth rate; $F C R=$ feed conversion ratio; SURV = survival rate.

*MT $=17$ alpha-methyltestosterone $(0.6 \mathrm{~g} / \mathrm{kg})$

For growth performance parameters, FW and WG of fish fed the PP diets were significantly higher than those fed the MT and control diets $(p<0.05$; Table 3$)$. FI of all fish receiving the experimental diets was statistically similar $(p>0.05)$. All groups fed the PP and the control diets exhibited significantly higher SGR than did the MT group $(p<0.05)$; specifically, fish fed PP at $0.08 \mathrm{~g} / \mathrm{kg}$ diet exhibited significantly higher SGR than those fed the MT diet $(p<0.05)$. The MT group exhibited lower food conversion efficiency (i.e. higher FCR) than the control and PP groups implying that the MT diet did not affect feed utilization. Survival rate in all dietary treatments was high $(68.0 \%$ to $78.7 \%$ ) considering that mortality could be considerably high at larval stages.

The specific enzyme activities of the larvae at $0,0.32 \mathrm{~g}$ (middle dose) and $0.0 .64 \mathrm{~g}$ (high dose) PP/kg of feed are shown in Table 4. Fish fed the control and PP diets exhibited statistically similar specific activity of alpha amylase $(p>0.05)$. In contrast, PP significantly increased trypsin activity (2.7-times) for the diet containing $0.32 \mathrm{~g} / \mathrm{kg}$ PP to 3.0 times for the diet containing $0.64 \mathrm{~g} \mathrm{PP} / \mathrm{kg}$. 
Table 4. Specific activity of amylase and trypsin of Oreochromis niloticus fry fed $0,0.32$ and 0.64 $\mathrm{g} / \mathrm{kg}$ pine pollen for 14 days.

\begin{tabular}{lll}
\hline $\begin{array}{l}\text { Pine pollen } \\
(\mathrm{g} / \mathrm{kg})\end{array}$ & $\begin{array}{l}\text { Amylase } \\
(\mathrm{mg} \text { maltose } / \mathrm{h} / \mathrm{mg} \text { protein })\end{array}$ & $\begin{array}{l}\text { Trypsin } \\
\left(\mu \mathrm{mol} p \text {-nitroaniline } / \mathrm{h}^{\prime} \mathrm{mg} \text { protein }\right)\end{array}$ \\
\hline 0 & $21.7 \pm 1.1^{\mathrm{a}}$ & $34.6 \pm 3.6^{\mathrm{a}}$ \\
0.32 & $22.0 \pm 0.5^{\mathrm{a}}$ & $91.7 \pm 4.7^{\mathrm{b}}$ \\
0.64 & $24.2 \pm 0.5^{\mathrm{a}}$ & $103.8 \pm 19.1^{\mathrm{b}}$ \\
\hline
\end{tabular}

\section{Discussion}

The short-period of attractability ( $5 \mathrm{~min}$ ) of the PP diet over the control diet was an indication that a certain component of the PP served as a feeding stimulant. This short period of attractability probably stemmed from the use of an already attractive commercial diet as basal diet, replete with natural feeding stimulant such as fish meal and other marine origin ingredients. A study on feed attractability in blue shrimp, Litopenaeus stylirostris, used a formulated bland diet as their basal diet (Suresh et al, 2011). They noted that the shrimp took a longer time $(10 \mathrm{~min})$, to react to the test feed. Nile tilapia in the present study, in contrast, responded in seconds; mobility seemed to be the main difference between the reaction times of the shrimp and the Nile tilapia in the present study. Our observations were in agreement with observation in goldfish in which the handling time was completed in 3-5 s with unflavored pellets, and 30-60 s with moderately aversive stimuli in pellets (Lamn \& Finger, 1995). Although attraction to the PP diet was short-lived and became insignificant in $6 \mathrm{~min}$, it was at least apparent that the Nile tilapia were not repelled by the PP diet. Feed that does not taste right, does not taste at all, or feed which contains bitter compounds, is rejected after touching the fish mouth (Mackie, 1982). Moreover, in the growth trial of the present study, FI was statistically similar in all dietary treatments confirming that the fish were not repelled by the PP diet. In fish, all compounds known to be stimulatory are small, water soluble, and non-volatile (Olsen \& Lundh, 2016). Pollen of Pinus tabulaeformis should also be analyzed for its composition since it displayed a quick stimulatory effect on Nile tilapia.

PP diets and the MT diet in the present study resulted in statistically similar sex inversion percentages. This inversion rate agrees well with those of Okoko (1996) who obtained rates of $98.3 \%, 99.3 \%$, and $97.0 \%$, with MT of 15,30 and $60 \mathrm{mg} / \mathrm{kg}$ in Oreochromis niloticus. Feeding MT diets to tilapia larvae for sex inversion is the current practice in the aquaculture industry. PP diets, however, are more cost-effective and potentially very acceptable to the market given that PP comes from a natural source. More studies however, should be conducted on the length of time phytosteroid residues remain in water and soil compared with those of MT. More importantly, a study should be conducted on the characterization of the shelf life and storage requirements of PP. In our case, we purchased $2 \mathrm{~kg}$ PP from China receiving it in a regular sack made of polyethylene, stored at ambient temperatures.

We assume that phytosteroids in PP are combinations of different sex steroids. The pollen of Pinus silvestris is reported to contain $80 \mathrm{ng} / \mathrm{g}$ testosterone, $110 \mathrm{ng} / \mathrm{g}$ epitestosterone, and $590 \mathrm{ng} / \mathrm{g}$ androstenedione (Saden-Krehula et al, 1971). Although the estimated total phytosteroid in the pine pollen in the present study was only $1.3 \%$ of that in the MT diet $(60 \mathrm{mg} / \mathrm{kg})$ based on the chemical analyses of Pinus silvestris, the androgenic potency of PP was statistically similar to that of MT. This could be the basis for cost-effectiveness of PP making it a suitable candidate for the replacement of MT. We purchased the PP powder that we used in this study at $57 \mathrm{USD} / \mathrm{kg}$ while the MT came in a small bottle containing $10 \mathrm{~g}$ at an estimated cost of 2,800 USD/kg.

Androgens have both androgenic and anabolic effects. The present study showed that a PP diet at $0.08 \mathrm{mg} / \mathrm{kg}$ was more efficient than a diet of $0.6 \mathrm{mg} \mathrm{MT} / \mathrm{kg}$ in enhancing FW and SGR in the Nile tilapia, and the PP was more effective in promoting growth than MT. In addition, FCR was significantly better in fish fed diets containing 0.08 and $0.32 \mathrm{~g}$ $\mathrm{PP} / \mathrm{kg}$ than those fed diets containing MT at $60 \mathrm{mg} / \mathrm{kg}$ (considered optimum level for Nile tilapia for sex inversion by El-Greisy and Gamal, 2012). Anabolic effects could be manifested as increases in individual growth of tilapia (Little et al, 2003) and/or 
improvement in FCR (Chakraborty \& Banerjee, 2010). In the present study, anabolic effects were observed consistently in terms of FW, SGR, and FCR of the fish fed the PP diet at $0.08 \mathrm{mg} / \mathrm{kg}$. At this low PP concentration, anabolism was already apparent; whether or not anabolism disappears or becomes inhibitory at higher concentrations of PP remains to be investigated. The statistically similar PER in all treatments in the present study implied that PP diet did not stimulate protein deposition, which is the expected action of steroids in some fish (Matty \& Lone, 1985). However, enhancement by PP of the specific activity of trypsin in PP-fed tilapia in the present study could be the initial enhancement of protein utilization but was not manifested in the PER and FCR results. The diets had no effect on the specific activity of alpha amylase; no elevation was observed in fish fed diets containing PP or MT, implying that starch components of feed are utilized in the gut at normal rates.

In conclusion, the diet containing PP initially elicited apparent stimulation of feeding for the first $5 \mathrm{~min}$ but more importantly, it did not repel the fish. PP potency was statistically similar to MT in effecting artificial sex reversal in the Nile tilapia. PP showed a slight anabolic effect especially at the lowest dosage of $0.08 \mathrm{mg} / \mathrm{kg}$, and significantly more than MT.

\section{Acknowledgements}

The authors are grateful to the Philippine Department of Science and Technology (DOST)-Accelerated Science and Technology Human Resource Development Program (ASTHRDP) for providing a scholarship to Ms. Cherry T. Nian and additional publication support. Appreciation also to the Office of the Vice Chancellor for Research and Extension of the University of the Philippines Visayas for additional research funding. The authors are also grateful to Mr. John Madamba and Abe Corpuz for the methyltestosterone and Mr. Vicente Nim for technical help.

\section{References}

Bernfeld P., 1955 Amylases, A and B. In: Colowick S.P., Kaplan N.O. (Eds.), Methods in Enzymology, Vol. 1, Academic Press, New York, USA. pp. 147-150.

Bhasin, S., Bagatell, C.J., Bremner, W. J., Plymate, S.R., Tenover, J.L., Korenman, S.G., Nielschlag, E., 1998. Issues in testosterone replacement in old men. J. Clinical Endocrinol. Metab. 83: 3435-3448.

Bradford, M.M. 1976. A rapid and sensitive method for the quantification of microgram quantities of protein utilizing the principle of protein dye binding. Anal. Biochem., 72: 248-254.

Chakraborty, S.B., Banerjee, S., 2010. Comparative growth performance of mixed-sex and monosex Nile tilapia population in freshwater cage culture system under Indian perspective. Int. J. Biol., 2 (1), 44-50.

El-Greisy, Z.A., El-Gamal, A.E., 2012. Monosex production of tilapia, Oreochromis niloticus using different doses of 17 alpha methyltestosterone with respect to the degree of sex stability after one year of treatment. Egyptian J. Aquat. Res., 38: 59-66.

Geiger, R., Fritz, H. 1988. Trypsin. In: Methods of enzymatic analysis. Vol.V. Beigmeyer J., Grab, M. (eds), Weinheim: Chemie Verlag, pp.119-129.

Jones, J. L., Roddick, J. G., 1988. Steroidal estrogens and androgens in relation to reproductive development in higher plants. J. Plant Physiol., 133:510-518.

Lamn, C.F., Finger, T.E., 1995. Gustatory control of feeding behavior in goldfish. Physiol. Behav., 57(3): 483-438.

Little, D.C., Bhujel, R.C., Pham, T.A., 2003. Advanced nursing of mixed-sex and mono-sex tilapia (Oreochromis niloticus) fry, and its impact on subsequent growth in fertilized ponds. Aquaculture, 221: 265-276.

Mackie, A.M., 1982. Identification of the Gustatory Feeding Stimulants In: T.J. Hara (ed) Fish Chemoreception. Fish and Fisheries Series 6, Chapman and Hall, London (1982). pp 275-291.

Matty, A. J., Lone, K. P., 1985. Hormonal control of protein deposition. In: Cowey, C. B.; Mackie, A. M.; Bell, J. G., eds. Nutrition and Feeding in Fish. Academic Press. pp. 147-167. 
Okoko, M. 1996. Effect of 17a-methyltestosterone concentrations on the sex ratio, and gonadal development of Nile tilapia Oreochromis niloticus. Master's Thesis, Auburn University, AL, USA.

Olsen, K.H., Lundh, T., 2016. Feeding stimulants in an omnivorous species, crucian carp Carassius carassius (Linnaeus 1758). Aquacult. Rep., 4: 66-73.

Pandian, T.J., Sheela, S.G., 1995. Hormonal induction of sex reversal in fish. Aquaculture, 138: 1-22.

Saden-Krehula, M., Tajic, M, Kolbah, D., 1971. Testosterone, epitestosterone and androstenedione in the pollen of Scotch pine P. Silvestris L. Experientia 27(1): 108-109.

Serrano, A.E.J., Traifalgar, R.F.M., 2012. Ontogeny and induction of digestive enzymes in Scylla serrata larvae fed live or artificial feeds or their combination. $A A C L$ Bioflux 5(3): 101- 111.

Suresh, A.V., Kumaraguru vasagan, K.P., Nates, S. 2011. Attractability and palatability of protein ingredients of aquatic and terrestrial animal origin and their practical value for blue shrimp, Litopenaeus stylirostris fed diets formulated with high levels of poultry byproduct meal. Aquaculture, 319: 132-140.

Tacio, H.D. 2014. Managing tilapia farms sustainably to feed the poor. Gaia Discovery, http://www.gaiadiscovery.com/technology-innovation/managing-tilapia-farms-

sustainably-to-feed-the-poor.html. Accessed on April 7, 2017.

Velle, W., 1982. The Use of Hormones in Animal Production. FAP Animal Production and Health Papers, 31: 53.

Zhong-han, Y., Yin, T., Zong-xun, C., Tsao, T.H., 1994. The changes of steroidal sex hormone - testosterone contents in reproductive organs of Lilium davidii Duch. Acta Bot. Sin. 36: 215-220. 